\title{
Studies on the Growth Rate of Silkworm Bombyx mori (L.) (Lepidoptera: Bombycidae) Fed with Control and Silver Nanoparticles (AgNps) Treated $\mathrm{MR}_{2}$ Mulberry Leaves
}

\author{
Ponraj Ganesh Prabu*, Selvi Sabhanayakam, Veeranarayanan Mathivanan, \\ and Dhananjayan Balasundaram \\ Department of Zoology, Annamalai University, Annamalainagar - 608 002, Tamilnadu, India
}

(Received 10 December 2010; Accepted 26 March 2011)

To evaluate the growth rate of larval and pupal parameters of silkworm Bombyx mori fed with Silver Nanoparticles (AgNps) treated $M_{2}$ mulberry leaves, the following works have been considered. The AgNp was synthesized by chemical reduction method, it was diluted by different concentrations such as $25 \%, 50 \%$, $\mathbf{7 5 \%}$ and $100 \%$ (without dilution). Fresh mulberry leaves (Morus alba L.) were sprayed by each concentration and were fed to silkworms, from $3^{\text {rd }}, 4^{\text {th }}$ and $5^{\text {th }}$ instar, five feedings/day. Group $T_{1}$ larvae received $M_{2}$ mulberry leaves sprayed with distilled water and served as control, group $\mathbf{T}_{2}, \mathbf{T}_{3}, \mathbf{T}_{4}$ and $\mathbf{T}_{5}$ larvae received $25 \%, 50 \%, 75 \%$ and $100 \%$ AgNps sprayed mulberry leaves, respectively. Silkworm larvae fed on M. alba $\left(\mathrm{MR}_{2}\right)$ leaves sprayed with $\mathbf{2 5 \%}$ concentration of AgNps (group $T_{2}$ ) was significantly increased the larvae and cocoon length, width and weight as compared to those fed on control (group $T_{1}$ ) $\mathbf{M R}_{2}$ mulberry leaves and other groups $\left(T_{3}, T_{4}\right.$ and $\left.T_{5}\right)$. Hence, $\mathbf{2 5 \%}$ AgNps dose was fixed as an effective dose. It has been observed from the present study that 25\% AgNps treated (group $T_{2}$ ) leaves fed by silkworms have enhanced the larval and pupal growth and quantity of silk production than control.

Key words: Bombyx mori, Morus alba, Silver nanoparticles (AgNps), $\mathrm{MR}_{2}$ Mullbery leaves

\footnotetext{
*To whom the correspondence addressed

P. Ganesh Prabu, Department of Zoology, Annamalai University, Annamalainagar - 608 002, Tamilnadu, India. Tel \& Fax: +09843080005; E-mail: ganeshprabu79@gmail.com
}

\section{Introduction}

The silkworm Bombyx mori rearing is a traditional industry in Asia and the life of many people is depended on it. Increase of larval growth and cocoon quality and quantity would result better economics for this industry and meet the production needs. Consequently, the enrichment of mulberry leaves by supplementary compounds with the aim of increasing the production of cocoon is a very important aspect. Many investigations have been done on this topic and various reports have been published (Eteberi, 2002; Etebari et al., 2004; Islam et al., 2004). Fortification of mulberry leaves with complementary compounds was found to increase the larval growth and post cocoon characteristics (Etebari, 2002; Etebari and Fazilati, 2003).

Ionic silver has a long history of use in topical medical applications, and it has been shown that ionic silver, in the right quantities, is suitable in treating wounds (Qin et al., 2005; Hermans, 2006; Chopra, 2007; Atiyeh et al., 2007). The US Food and Drug Administration have approved the use of a range of different silver-impregnated wound dressings. Silver nanoparticles are now replacing silver sulfadiazine as an effective agent in the treatment of wounds (Lansdown, 2006; Atiyeh et al., 2007). These Silver nanoparticles are under active research because they posses interesting physical properties differing considerably from that of the bulk phase. It comes from small sizes and high surface/ volume ratio (Patel et al., 2005). Metallic silver colloids were first prepared more than a century ago. Ag nanoparticles can be synthesized using various methods: chemical, electrochemical (Vorobyova et al., 1995). The most popular preparation of $\mathrm{Ag}$ colloids is chemical reduction of silver salts by Tri sodium citrate. This preparation is simple, but the great care must be exercised to make stable and reproducible colloid. The purity of water and reagents, cleanliness of the 
glassware are critical parameters. Solution temperature, concentrations of the metal salt and reducing agent, reaction time influences particle size. Controlling size and shape of metal nanoparticles remains a challenge (Bell et al., 2001).

Nutrition plays an important role in improving the growth and development of the silkworm, B. mori L. like other organisms. Legay, (1958) has stated that silk production is dependent on the larval nutrition and nutritive value of mulberry leaves plays a very effective role in producing good quality cocoons. Seki and Oshikane, (1959) have observed better growth and development of silkworm larvae as well as good quality cocoons when fed on nutritionally enriched leaves. Silkworms obtain its entire nutritional requirement from mulberry leaves because this insect is monophagous and can complete the life cycle on mulberry leaves exclusively. Studies of Ito, (1978) have determined that generally vitamins present in the mulberry leaves satisfy minimum needs of silkworm but the amount of vitamins present in mulberry leaves varies on the basis of environmental conditions, usage of fertilizers in field and mulberry varieties and other field practices. Sengupta et al. (1972) have showed that B. mori requires specific essential sugars, amino acids, proteins and vitamins for its normal growth, survival and also for the silk gland activity and growth. Akhtar and Asghar, (1972) have found that vitamins and mineral salts played an important role in the nutrition of silkworm. Keeping the importance of vitamins and other compounds like silver nanoparticles on silkworm nutrition are very effective. Mulberry silkworm (B. mori) sustains its nutrition from its food plants of Morus alba. The nutritional levels of $\mathrm{MR}_{2}$ mulberry influence the larval growth of silkworm mulberry leaves treated with some other compounds like silver nanoparticles, which ultimately influence the economic traits such as silk yield, larval and cocoon parameters (Lengh, width and weight). The present study has been aimed to find out the feed efficacy of AgNps treated $\mathrm{MR}_{2}$ mulberry leaves with regard to food utilization by larvae and ultimate impact on the cocoon parameters of silkworm so as to spot out the most nutritive one for bivoltine silkworm in Tamilnadu climatic conditions. The work is related to the studies on the growth rate of $B$. mori fed with control and silver nanoparticles treated $\mathrm{MR}_{2}$ mulberry leaves are fragmentary. Therefore, this study has been carried out to know the impact of silver nanoparticles on B. mori.

\section{Materials and Methods}

The eggs of silkworm B. mori LNB4, D2 (Local Bivoltine) race were collected from farmers training centre at Jayankondapattinam, Tamilnadu, India. The eggs were placed at ambient temperature of $25 \pm 2^{\circ} \mathrm{C}$ and relative humidity of 70 to $80 \%$ in an incubator for hatching. After hatching, larvae were isolated from stock culture. The larvae were divided into 5 experimental groups including controls (distilled water control), each group consisting of 6 larvae. The larvae were reared in card board boxes measuring $22 \times 15 \times 5 \mathrm{cms}$ covered with polythene sheet and placed in an iron stand with ant wells. The larvae were subjected to the following treatments. AgNps were synthesized by chemical reduction method. It was diluted in distilled water $25 \%, 50 \%, 75 \%$ and $100 \%$ (without dilution) concentrations. Fresh mulberry leaves were sprayed by each concentration and then dried in air for 10 minutes. The supplementary leaves were fed to silkworms, five feedings / day. Group $T_{1}$ larvae received mulberry leaves sprayed with distilled water and served as control, group $\mathrm{T}_{2}$ larvae received $25 \%$ AgNps sprayed mulberry leaves, group $\mathrm{T}_{3}$ larvae received 50\% AgNps sprayed mulberry leaves, group $\mathrm{T}_{4}$ larvae received $75 \%$ AgNps sprayed mulberry leaves, group $T_{5}$ larvae received $100 \%$ AgNps sprayed mulberry leaves, respectively and they were maintained up to cocoon. $3^{\text {rd }}, 4^{\text {th }}$ and $5^{\text {th }}$ instar larvae length, width and weight, cocoon length, width and weight were determined for all groups.

\section{Preparation of Silver Nanoparticles (AgNps)}

Silver nitrate $\mathrm{AgNO}_{3}$ (Sigma Aldrich, UK) and Trisodium Citrate $\mathrm{C}_{6} \mathrm{H}_{5} \mathrm{O}_{7} \mathrm{Na}_{3}$ (Sigma Aldrich, UK) of analytical grade purity, were used as starting materials without further purification. The silver colloid was prepared by using chemical reduction method according to the description of Lee and Meisel, (1982). All solutions of reacting materials were prepared in distilled water. In typical experiment, $50 \mathrm{ml}$ of $1 \cdot 10^{-3} \mathrm{M} \mathrm{AgNO} 3$ was heated to boiling. To this solution, $5 \mathrm{ml}$ of $1 \%$ Trisodium Citrate was added drop by drop. During the process, solution was mixed vigorously. Solution was heated until color's change is evident (pale yellow). Then it was removed from the heating element and stirred until cooled at room temperature.

Mechanism of reaction could be expressed as follows:

$$
\begin{aligned}
& 4 \mathrm{Ag}^{+}+\mathrm{C}_{6} \mathrm{H}_{5} \mathrm{O}_{7} \mathrm{Na}_{3}+2 \mathrm{H}_{2} \mathrm{O} \rightarrow \\
& 4 \mathrm{Ag} 0+\mathrm{C}_{6} \mathrm{H}_{5} \mathrm{O}_{7} \mathrm{H}_{3}+3 \mathrm{Na}^{++}+\mathrm{H}^{+}+\mathrm{O}_{2} \uparrow
\end{aligned}
$$

\section{Mulberry (M. alba) $\mathbf{M R}_{\mathbf{2}}$ variety}

This is one of the varieties of mulberries selected from Jayamkondapattinam sericulture farm. Branches are simple, vertical, grayish leaves are darkly green, unlobed, elliptic, palmate, veined, and leathery/smooth/wrinkled. It has good agronomy characters like high rooting ability $(80 \%)$.

\section{Mulberry (M. alba) $\mathrm{MR}_{2}$ leaves treated with Silver Nanoparticles (AgNps)}

AgNps was prepared by chemical reduction method 
Table 1. Morphometric data of various concentrations of $\mathrm{AgNps}$ treated with $\mathrm{MR}_{2}$ mulberry leaves on the $3^{\text {rd }}$ instars larvae length, width and weight of Bombyx mori.

\begin{tabular}{cccc}
\hline & $3^{\text {rd }}$ instar larvae & \\
\hline Groups & $\begin{array}{c}\text { Length }(\mathrm{cm}) \\
(\text { Mean } \pm \text { S.D })\end{array}$ & $\begin{array}{c}\text { Width }(\mathrm{cm}) \\
(\text { Mean } \pm \text { S.D) }\end{array}$ & $\begin{array}{c}\text { Weight (gm) } \\
(\text { Mean } \pm \text { S.D) }\end{array}$ \\
\hline Control $\left(\mathrm{T}_{1}\right)$ & $1.6833 \pm 0.14720^{\mathrm{a}}$ & $0.3500 \pm 0.05477^{\mathrm{a}}$ & $0.1117 \pm 0.00753^{\mathrm{ab}}$ \\
\hline $\mathrm{MR}_{2}$ mulberry+25\% AgNps $\left(\mathrm{T}_{2}\right)$ & $1.9333 \pm 0.16330^{\mathrm{b}}$ & $0.3833 \pm 0.04082^{\mathrm{a}}$ & $0.1233 \pm 0.01033^{\mathrm{b}}$ \\
\hline $\mathrm{MR}_{2}$ mulberry+50\% AgNps $\left(\mathrm{T}_{3}\right)$ & $1.8500 \pm 0.10488^{\mathrm{ab}}$ & $0.3500 \pm 0.05477^{\mathrm{a}}$ & $0.1100 \pm 0.00894^{\mathrm{a}}$ \\
\hline $\mathrm{MR}_{2}$ mulberry+75\% AgNps $\left(\mathrm{T}_{4}\right)$ & $1.8833 \pm 0.14720^{\mathrm{b}}$ & $0.3500 \pm 0.05477^{\mathrm{a}}$ & $0.1150 \pm 0.01049^{\mathrm{ab}}$ \\
\hline $\mathrm{MR}_{2}$ mulberry+100\% AgNps $\left(\mathrm{T}_{5}\right)$ & $1.8667 \pm 0.13663^{\mathrm{b}}$ & $0.3667 \pm 0.05164^{\mathrm{a}}$ & $0.1133 \pm 0.00816^{\mathrm{ab}}$ \\
\hline
\end{tabular}

Values are Mean \pm S.D of six observations. Values in the same column with different superscript letters (a \& b) differs significantly at $\mathrm{P}<0.05$ (DMRT).

according to Lee and Meisel (1982). It was diluted to $25 \%, 50 \%, 75 \%$ and $100 \%$ (without dilution) concentrations. Fresh mulberry leaves were soaked in each concentration for 15 minutes and then were dried in air for 10 minutes. The treated leaves were used for feeding the $3^{\text {rd }}$, $4^{\text {th }}$ and $5^{\text {th }}$ instar larvae of silkworm B. mori.

\section{Statistical analysis}

Data were analyzed by one way analysis of variance (ANOVA) followed by Duncan's multiple range test (DMRT) using a commercially available statistics software package (SPSS ${ }^{\circledR}$ for Windows, V. 16.0, Chicago, USA). Results were presented as means $\pm \mathrm{SD}$. P values $<$ 0.05 were regarded as statistically significant.

\section{Results}

\section{Larval Parameters \\ Morphometric analysis of $3^{\text {rd }}, 4^{\text {th }}$ and $5^{\text {th }}$ instar larvae than control}

Table 1 shows that the Morphometric data of length, width and weight of larval parameters of $B$. mori fed with control $\mathrm{MR}_{2}$ leaves and $\mathrm{AgNps}$ treated $\mathrm{MR}_{2}$ leaves in $3^{\text {rd }}$ instar larvae of $B$. mori. The mean length, width and weight of $3^{\text {rd }}$ instar larvae of group $T_{1}$ were $(1.6833 \pm 0.14720 \mathrm{~cm}$, $0.3500 \pm 0.05477 \mathrm{~cm}$ and $0.1117 \pm 0.00753 \mathrm{gm})$, respectively. The mean length, width and weight of $3^{\text {rd }}$ instar larvae of group $\mathrm{T}_{2}$ were $(1.9333 \pm 0.16330 \mathrm{~cm}, 0.3833 \pm$ $0.04082 \mathrm{~cm}$ and $0.1233 \pm 0.01033 \mathrm{gm})$, respectively. The mean length, width and weight of $3^{\text {rd }}$ instar larvae of group $\mathrm{T}_{3}$ were $(1.8500 \pm 0.10488 \mathrm{~cm}, 0.3500 \pm 0.05477 \mathrm{~cm}$ and $0.1100 \pm 0.00894 \mathrm{gm})$, respectively. The mean length, width and weight of $3^{\text {rd }}$ instar larvae of group $\mathrm{T}_{4}$ were $(1.8833 \pm 0.14720 \mathrm{~cm}, 0.3500 \pm 0.05477 \mathrm{~cm}$ and $0.1150 \pm$ $0.01049 \mathrm{gm})$, respectively. The mean length, width and weight of $3^{\text {rd }}$ instar larvae of group $\mathrm{T}_{5}$ were $(1.8667 \pm$ $0.13663 \mathrm{~cm}, 0.3667 \pm 0.05164 \mathrm{~cm}$ and $0.1133 \pm 0.00816 \mathrm{gm})$, respectively. In these five observations, $25 \% \mathrm{AgNps}$ treated $3^{\text {rd }}$ instar larvae length, width and weight were significantly increased than the other four groups $\left(\mathrm{T}_{1}, \mathrm{~T}_{3}, \mathrm{~T}_{4}\right.$ and $\left.\mathrm{T}_{5}\right)$.

Table 2 shows that the Morphometric data of length, width and weight of larval parameters of $B$. mori fed with control $\mathrm{MR}_{2}$ leaves and $\mathrm{AgNps}$ treated $\mathrm{MR}_{2}$ leaves in $4^{\text {th }}$ instar larvae of $B$. mori. The mean length, width and weight of $4^{\text {th }}$ instar larvae of group $\mathrm{T}_{1}$ were $(5.7333 \pm 0.24221 \mathrm{~cm}, 0.5333 \pm 0.08165 \mathrm{~cm}$ and $0.4233 \pm$ $0.03445 \mathrm{gm})$, respectively. The mean length, width and weight of $4^{\text {th }}$ instar larvae of group $\mathrm{T}_{2}$ were $(6.0167 \pm 0.14720 \mathrm{~cm}, 0.6167 \pm 0.07528 \mathrm{~cm}$ and $0.5450 \pm$ $0.04037 \mathrm{gm})$, respectively. The mean length, width and weight of $4^{\text {th }}$ instar larvae of group $\mathrm{T}_{3}$ were $(5.4500 \pm$ $0.18708 \mathrm{~cm}, 0.6000 \pm 0.08944 \mathrm{~cm}$ and $0.4350 \pm 0.03834 \mathrm{gm})$, respectively. The mean length, width and weight of $4^{\text {th }}$ instar larvae of group $\mathrm{T}_{4}$ were $(5.4500 \pm 0.20736 \mathrm{~cm}$, $0.6500 \pm 0.05477 \mathrm{~cm}$ and $0.4150 \pm 0.02739 \mathrm{gm})$, respectively. The mean length, width and weight of $4^{\text {th }}$ instar larvae of group $\mathrm{T}_{5}$ were $(5.4000 \pm 0.20976 \mathrm{~cm}, 0.6500 \pm$ $0.05477 \mathrm{~cm}$ and $0.4150 \pm 0.02429 \mathrm{gm})$, respectively. In these five observations, $25 \% \mathrm{AgNps}$ treated $4^{\text {th }}$ instar larvae length, width and weight were significantly increased than the other four groups $\left(\mathrm{T}_{1}, \mathrm{~T}_{3}, \mathrm{~T}_{4}\right.$ and $\left.\mathrm{T}_{5}\right)$.

Table 3 shows that the Morphometric data of length, width and weight of larval parameters of $B$. mori fed with control $\mathrm{MR}_{2}$ leaves and $\mathrm{AgNps}$ treated $\mathrm{MR}_{2}$ leaves in $5^{\text {th }}$ instar larvae of B. mori. The mean length, width and weight of $5^{\text {th }}$ instar larvae of group $T_{1}$ were $(6.7167 \pm 0.24833 \mathrm{~cm}, 1.0333 \pm 0.12111 \mathrm{~cm}$ and $2.8350 \pm$ $0.08550 \mathrm{gm})$, respectively. The mean length, width and weight of $5^{\text {th }}$ instar larvae of group $T_{2}$ were $(7.2500 \pm$ $0.18708 \mathrm{~cm}, 1.1333 \pm 0.08165 \mathrm{~cm}$ and $3.5583 \pm 0.23693 \mathrm{gm})$, respectively. The mean length, width and weight of $5^{\text {th }}$ 
Table 2. Morphometric data of various concentrations of AgNps treated with $\mathrm{MR}_{2}$ mulberry leaves on the $4^{\text {th }}$ instars larvae length, width and weight of Bombyx mori.

\begin{tabular}{cccc}
\hline \multicolumn{4}{c}{$4^{\text {th }}$ instar larvae } \\
\hline Groups & $\begin{array}{c}\text { Length }(\mathrm{cm}) \\
(\text { Mean } \pm \text { S.D })\end{array}$ & $\begin{array}{c}\text { Width }(\mathrm{cm}) \\
(\text { Mean } \pm \text { S.D) }\end{array}$ & $\begin{array}{c}\text { Weight (gm) } \\
(\text { Mean } \pm \text { S.D) }\end{array}$ \\
\hline Control $\left(\mathrm{T}_{1}\right)$ & $5.7333 \pm 0.24221^{\mathrm{b}}$ & $0.5333 \pm 0.08165^{\mathrm{a}}$ & $0.4233 \pm 0.03445^{\mathrm{a}}$ \\
\hline $\mathrm{MR}_{2}$ mulberry+25\% AgNps $\left(\mathrm{T}_{2}\right)$ & $6.0167 \pm 0.14720^{\mathrm{c}}$ & $0.6167 \pm 0.07528^{\mathrm{ab}}$ & $0.5450 \pm 0.04037^{\mathrm{b}}$ \\
\hline $\mathrm{MR}_{2}$ mulberry+50\% AgNps $\left(\mathrm{T}_{3}\right)$ & $5.4500 \pm 0.18708^{\mathrm{a}}$ & $0.6000 \pm 0.08944^{\mathrm{ab}}$ & $0.4350 \pm 0.03834^{\mathrm{a}}$ \\
\hline $\mathrm{MR}_{2}$ mulberry+75\% AgNps $\left(\mathrm{T}_{4}\right)$ & $5.4500 \pm 0.20736^{\mathrm{a}}$ & $0.6500 \pm 0.05477^{\mathrm{b}}$ & $0.4150 \pm 0.02739^{\mathrm{a}}$ \\
\hline $\mathrm{MR}_{2}$ mulberry+100\% AgNps $\left(\mathrm{T}_{5}\right)$ & $5.4000 \pm 0.20976^{\mathrm{a}}$ & $0.6500 \pm 0.05477^{\mathrm{b}}$ & $0.4150 \pm 0.02429^{\mathrm{a}}$ \\
\hline
\end{tabular}

Values are Mean \pm S.D of six observations. Values in the same column with different superscript letters (a \& b) differs significantly at $\mathrm{P}<0.05$ (DMRT).

Table 3. Morphometric data of various concentrations of $\mathrm{AgNps}$ treated with $\mathrm{MR}_{2}$ mulberry leaves on the $5^{\text {th }}$ instars larvae length,width and weight of Bombyx mori.

\begin{tabular}{cccc}
\hline & $5^{\text {th }}$ instar larvae & \\
\hline Groups & $\begin{array}{c}\text { Length }(\mathrm{cm}) \\
(\text { Mean } \pm \text { S.D })\end{array}$ & $\begin{array}{c}\text { Width }(\mathrm{cm}) \\
(\text { Mean } \pm \text { S.D })\end{array}$ & $\begin{array}{c}\text { Weight (gm) } \\
(\text { Mean } \pm \text { S.D) }\end{array}$ \\
\hline Control $\left(\mathrm{T}_{1}\right)$ & $6.7167 \pm 0.24833^{\mathrm{a}}$ & $1.0333 \pm 0.12111^{\mathrm{ab}}$ & $2.8350 \pm 0.08550^{\mathrm{a}}$ \\
\hline $\mathrm{MR}_{2}$ mulberry+25\% AgNps $\left(\mathrm{T}_{2}\right)$ & $7.2500 \pm 0.18708^{\mathrm{c}}$ & $1.1333 \pm 0.08165^{\mathrm{b}}$ & $3.5583 \pm 0.23693^{\mathrm{b}}$ \\
\hline $\mathrm{MR}_{2}$ mulberry+50\% AgNps $\left(\mathrm{T}_{3}\right)$ & $7.0000 \pm 0.17889^{\mathrm{bc}}$ & $1.0000 \pm 0.14142^{\mathrm{ab}}$ & $3.0950 \pm 0.59702^{\mathrm{a}}$ \\
\hline $\mathrm{MR}_{2}$ mulberry+75\% AgNps $\left(\mathrm{T}_{4}\right)$ & $6.9833 \pm 0.14720^{\mathrm{bc}}$ & $1.0000 \pm 0.06325^{\mathrm{ab}}$ & $3.2250 \pm 0.35229^{\mathrm{ab}}$ \\
\hline $\mathrm{MR}_{2}$ mulberry+100\% AgNps $\left(\mathrm{T}_{5}\right)$ & $6.7500 \pm 0.38341^{\mathrm{b}}$ & $0.9667 \pm 0.13663^{\mathrm{a}}$ & $2.9550 \pm 0.35809^{\mathrm{a}}$ \\
\hline
\end{tabular}

Values are Mean \pm S.D of six observations. Values in the same column with different superscript letters (a, b \& c) differs significantly at $\mathrm{P}<0.05$ (DMRT).

Table 4. Morphometric data of various concentrations of $\mathrm{AgNps}$ treated with $\mathrm{MR}_{2}$ mulberry leaves on the cocoon length, width and weight of Bombyx mori.

\begin{tabular}{cccc}
\hline \multicolumn{4}{c}{ Cocoon of Bombyx mori. } \\
\hline Groups & $\begin{array}{c}\text { Length }(\mathrm{cm}) \\
(\text { Mean } \pm \text { S.D) }\end{array}$ & $\begin{array}{c}\text { Width }(\mathrm{cm}) \\
(\text { Mean } \pm \text { S.D) }\end{array}$ & $\begin{array}{c}\text { Weight }(\text { gm }) \\
(\text { Mean } \pm \text { S.D) }\end{array}$ \\
\hline Control $\left(\mathrm{T}_{1}\right)$ & $3.4000 \pm 0.38471^{\mathrm{ab}}$ & $2.1333 \pm 0.12111^{\mathrm{a}}$ & $1.5117 \pm 0.10068^{\mathrm{a}}$ \\
\hline $\mathrm{MR}_{2}$ mulberry+25\% AgNps $\left(\mathrm{T}_{2}\right)$ & $3.6667 \pm 0.16330^{\mathrm{b}}$ & $2.4000 \pm 0.08944^{\mathrm{b}}$ & $2.2117 \pm 0.36318^{\mathrm{b}}$ \\
\hline $\mathrm{MR}_{2}$ mulberry+50\% AgNps $\left(\mathrm{T}_{3}\right)$ & $3.4000 \pm 0.12649^{\mathrm{ab}}$ & $2.0833 \pm 0.09832^{\mathrm{a}}$ & $1.5500 \pm 0.15633^{\mathrm{a}}$ \\
\hline $\mathrm{MR}_{2}$ mulberry+75\% AgNps $\left(\mathrm{T}_{4}\right)$ & $3.3167 \pm 0.24014^{\mathrm{a}}$ & $2.1167 \pm 0.11690^{\mathrm{a}}$ & $1.3967 \pm 0.18151^{\mathrm{a}}$ \\
\hline $\mathrm{MR}_{2}$ mulberry+100\% AgNps $\left(\mathrm{T}_{5}\right)$ & $3.3000 \pm 0.20976^{\mathrm{a}}$ & $2.1667 \pm 0.15055^{\mathrm{a}}$ & $1.5850 \pm 0.21961^{\mathrm{a}}$ \\
\hline
\end{tabular}

Values are Mean \pm S.D of six observations. Values in the same column with different superscript letters (a \& b) differs significantly at $\mathrm{P}<0.05$ (DMRT).

instar larvae of group $\mathrm{T}_{3}$ were $(7.0000 \pm 0.17889 \mathrm{~cm}$, $1.0000 \pm 0.14142 \mathrm{~cm}$ and $3.0950 \pm 0.59702 \mathrm{gm})$, respectively. The mean length, width and weight of $5^{\text {th }}$ instar larvae of group $\mathrm{T}_{4}$ were $(6.9833 \pm 0.14720 \mathrm{~cm}, 1.0000 \pm$ $0.06325 \mathrm{~cm}$ and $3.2250 \pm 0.35229 \mathrm{gm}$ ), respectively. The mean length, width and weight of $5^{\text {th }}$ instar larvae of group $\mathrm{T}_{5}$ were $(6.7500 \pm 0.38341 \mathrm{~cm}, 0.9667 \pm 0.13663 \mathrm{~cm}$ and $2.9550 \pm 0.35809 \mathrm{gm})$, respectively. In these five observations, $25 \% \mathrm{AgNps}$ treated $5^{\text {th }}$ instar larvae length, width and weight was significantly increased than the other four groups $\left(\mathrm{T}_{1}, \mathrm{~T}_{3}, \mathrm{~T}_{4}\right.$ and $\left.\mathrm{T}_{5}\right)$.

\section{Cocoon parameters}

Table 4 shows the Morphometric data of mean length, 
width and weight of the cocoon of $B$. mori fed with $\mathrm{AgNps}$ treated $\mathrm{MR}_{2}$ leaves were found to be more than that of the larvae fed with control $\mathrm{MR}_{2}$ leaves. The length, width and weight of the $T_{1}$ larvae produced cocoon were found to be about $(3.4000 \pm 0.38471 \mathrm{~cm}, 2.1333 \pm$ $0.12111 \mathrm{~cm}$ and $1.5117 \pm 0.10068 \mathrm{gm})$, respectively. The length, width and weight of the $T_{2}$ larvae produced cocoon were observed to be about $(3.6667 \pm 0.16330 \mathrm{~cm}$, $2.4000 \pm 0.08944 \mathrm{~cm}$ and $2.2117 \pm 0.36318 \mathrm{gm}$ ), respectively. The length, width and weight of the $\mathrm{T}_{3}$ larvae producing cocoon were observed to be about $(7.0000 \pm$ $0.17889 \mathrm{~cm}, 1.0000 \pm 0.14142 \mathrm{~cm}$ and $3.0950 \pm 0.59702 \mathrm{gm}$ ), respectively. The length, width and weight of the $T_{4}$ larvae produced cocoon were observed to be about (6.9833 \pm $0.14720 \mathrm{~cm}, 1.0000 \pm 0.06325 \mathrm{~cm}$ and $3.2250 \pm 0.35229 \mathrm{gm}$ ), respectively. The length, width and weight of the $T_{5}$ larvae produced cocoon were observed to be about $(6.7500$ $\pm 0.38341 \mathrm{~cm}, 0.9667 \pm 0.13663 \mathrm{~cm}$ and $2.9550 \pm 0.35809 \mathrm{gm})$, respectively. In these five observations, the $25 \% \mathrm{AgNps}$ treated larvae produced cocoon length, width and weight were significantly increased than the other four groups $\left(\mathrm{T}_{1}, \mathrm{~T}_{3}, \mathrm{~T}_{4}\right.$ and $\left.\mathrm{T}_{5}\right)$.

\section{Discussion}

In the present study, the larval and cocoon length, width and weight were significantly increased in some groups. Many researchers showed that the larval characters improve by different concentrations of complementary compounds such as ascorbic acid, folic acid, thiamin, vitamin B complex etc., (Sarker et al., 1995; Nirwani and Kaliwal, 1996, 1998; Etaberi et al., 2004; Balasundaram et al., 2008). Muniandy et al., (1995) have showed that multi-vitamins and mineral compounds could increase the food intake, growth and conversion efficiency of silkworm. In the present study, it has been observed that silkworms fed by the particular dose of AgNps have enhanced the larval length, width and weight and cocoon characters were concomitantly increased from $3^{\text {rd }}$ to $5^{\text {th }}$ instars, suggested that AgNps which were stimulate silkworm to feed more amount of nutrients intake than the control. This work is corroborated with Nirwani and Kaliwal, (1996), suggested that this enhancement in larval and cocoon length, width and weight related to phagostimulation of folic acid. Several authors also reported these effects about ascorbic acid (Dobzshenok, 1974; Ito, 1978; Singh and Reddy, 1981; Kl-Karkasy and Idriss, 1990).

Since most of this multi-vitamin compounds is composed of ascorbic acid, it could be thought that the increase of larval weight is due to an enhancement of feeding activity in treated larvae although the vitamins as cofactors can facilitate the metabolical pathway. Similar findings have also been observed in the present study that AgNps act as vitamins to stimulate the feeding activity in the silkworms. Therefore, AgNps can improve the food digestibility and increase the larval and cocoon length, width and weight.

In this study, cocoon parameters changed in different treatments. Previously, it was reported that enrichment of mulberry leaves by some vitamins could increase the cocoon yield. Nirwani and Kaliwal, (1996) have determined that folic acid causes a significant increase in economical parameters such as female and male cocoon weight. Evanglista et al. (1997) have also reported that the larval and cocoon length, width and weight increase under multi-vitamin treatment.

The enrichment of mulberry leaves with AgNps increase larval and cocoon length, width and weight increase in these insects was related to metabolisms other than proteins. It is assumed that fortification of diet supports the metabolism of carbohydrates and lipids, in conclusion, AgNps could increase some biological characteristics in silkworm, but this enhancement could economically improve the Sericulture goals.

In the present study, the treatment of AgNps at the concentration of $25 \%$ may have beneficial effects on the growth of the silkworm larval and pupal length, width and weight and also increased the quantity of silk production by enhancing the feed efficacy than control. So, this supplementation could be prescribed to the farmers to get more quantity of silk.

\section{Acknowledgement}

The authors are grateful to the authorities of Annamalai University, Annamalainagar. The help rendered by Dr. (Mrs.) Selvi Sabhanayakam, Professor and Head, Department of Zoology, Annamalai University, Annamalainagar is duly acknowledged.

\section{References}

Akhtar M, Asghar A (1972) Nutritional requirement of silkworm Bombyx mori. Pakistan. J Zool 4, 101-107.

Atiyeh BS, Costagliola M, Hayek SN, Dibo SA (2007) Effect of silver on burn wound infection control and healing: review of the literature Burns 33(2), 139-48.

Balasundaram D, Selvi S, Mathivanan V (2008) Studies on comparative feed efficacy of mulberry leaves MR2 and Mr2 treated with vitamin C on Bombyx moti (L.) (Lepidoptera: Bombycidae) in relation to larval parameters. J Curr Sci 
12(2), 677-682.

Bell WC, Myrick ML (2001) Preparation and Characterization of Nanoscale Silver Colloids by Two Novel Synthetic Routes. Journal of Colloid and Interface Science 242, 300305.

Chopra I (2007) The increasing use of silver-based products as antimicrobial agents: a useful development or a cause for concern. Journal of Antimicrobial Chemotherapy 59, 587.

Dobzhenok NV (1974) Effects of ascorbic acid on the physiological condition of the codling moth and its resistance to fungus and bacterial infection. Zakhist Roslin 19, 3-7.

El-Karaksy IA, Idriss M (1990) Ascorbic acid enhances the silk yield of the mulberry silkworm Bombyx mori. J Appl Entomol 109, 81-86.

Eteberi K (2002) Effect of enrichment of mulberry leaves (Morus alba) with some vitamins and nitrogenous compounds on some economic traits and physiological characters of silkworm Bombyx mori (Lepidoptera: Bombycidae). Isfahan University of Technology, Iran.

Etebari K, Fazilati M (2003) Effect of feeding on mulberry's supplementary leaves with multi-mineral in some biological and biochemical characteristics of silkworm (Bombyx mori). J Sci Technol Agric Natur Resour 7, 233-244.

Etebari K, Kaliwal B, Matindoost L (2004) Supplementation of mulberry leaves in sericulture, theoretical and applied aspects. Int. J Indust Entomol 9, 14-28.

Evangelista A, Carvalho AD, Takahashi R, De Carvalho AD (1997) Performance of silkworm (Bombyx mori L.) fed with vitamin and mineral supplement. Revista de Agriculture Piracicaba 72, 199-204.

Hermans MH (2006) Silver-containing dressings and the need for evidence. The American journal of nursing 106 (12), 608; quiz 6-89.

Islam MR, Ohayed Ali MA, Paul DK, Sultana S, Banu NA, Islam MR (2004) Effect of salt, nickel chloride supplementation on the growth of silkworm, Bombyx mori L. (Lepidoptera: Bombycidae). J Biol Sci 4, 170-172.

Ito T (1978) Silkworm Nutrition in the silkworm an important laboratory tool. Tazima Y (ed), 121-157, Ko. Ltd., Tokyo.

Lansdown AB (2006) Silver in health care: antimicrobial effects and safety in use. Current Problems in Dermatology 33, 17-34.

Lee PC, Meisel DJ (1982) Phys Chem 86, 3391-3395.

Legay JM (1958) Recent advances in silkworm nutrition. Ann Rev Ent 3, 75-86.

Muniandy S, Sheela M, Nirmala ST (1995) Effect of vitamins and minerals (Filibon) on food intake, growth and conversion efficiency in Bombyx mori. Environ Ecol 13, 433-435.

Nirwani RB, Kaliwal BB (1996) Effect of folic acid on economic traits and the change of some metabolic substances of bivoltine silkworm, Bombyx mori L. Korean J Seric Sci 38, 118-123.

Patel K, Kapoor S, Dave DP, Mukherjee T (2005) Synthesis of Nanosized Silver Colloids by Microwave Dielectric Heating. J Chem Sci 117 (1), 53-60.

Qin, Yimin (2005) Silver-containing alginate fibres and dressings. International Wound Journal 2, 172.

Sarker A, Haque M, Rab M, Absar N (1995) Effects of feeding mulberry (Morus sp.) leaves supplemented with different nutrients to silkworm (Bombyx mori) L. Curr Sci 69, 185188.

Sengupta K, Singh BD, Mustafi JC (1972) Nutrition of silkworm, Bombyx mori L. Studies on the enrichment of mulberry leaf with various sugars, proteins, amino acids and vitamins for vigorous growth of the worm and increased cocoon crop protection. Indian J Seric 11, 11-27.

Seki K, Oshikane K (1959) Res. Reports. Fac. Textile and Sericulture, Shinshu University.

Singh T, Reddy GP (1981) Feeding behaviour of castor semilooper, Achoea janata Linn. To sterols, ascorbic acid and castor leaves. Indian J Ectomol 50, 530-532.

Vorobyova SA, Lesnikovich AI, Sobal NS (1999) Preparation of Silver Nanoparticles by Interphase Reduction Colloids and Surfaces A: Physicochemical and Engineering Aspects $152,375-379$. 